\title{
Groundwater Management in India: Some Recent Breakthroughs
}

\author{
Subhajyoti Das \\ Geological Society of India, Bengaluru - 560 085, India \\ E-mail: subhajyoti_das@hotmail.com.
}

Received: 24 December 2021 / Revised form Accepted: 27 December 2021

(C) 2022 Geological Society of India, Bengaluru, India

\section{INTRODUCTION}

India has $16 \%$ of world's population but only $4 \%$ of its water resources reflecting acute skewness of water potential, though India's normal annual rainfall is $1100 \mathrm{~mm}$ much higher than the world average of $700 \mathrm{~mm}$. The climate is monsoonic and rainfall occurs in merely 100 days in a year. Inequity in its distribution in space and time is accentuated by climate change and global warming which are likely to jeopardize the water cycle precipitating extreme events more frequently. El Nino and La Nino will also set aside all speculations. Drinking water, sanitation and food production will be hit hard. With burgeoning population per capita water availability declined from $5177 \mathrm{~m}^{3} /$ year in 1951 to $1869 \mathrm{~m}^{3}$ in 2001 and is likely to be as low as $1140 \mathrm{~m}^{3}$ or less in 2050 foreboding serious water stress. Groundwater plays a major role in meeting the water needs

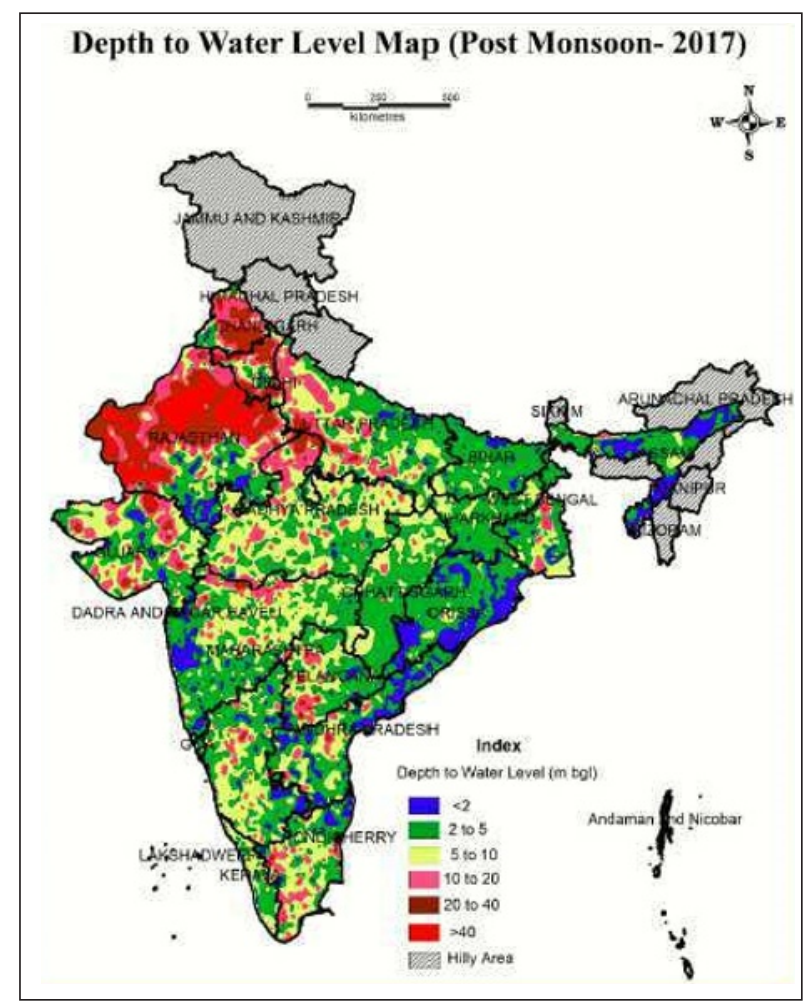

accounting for $66 \%$ of total irrigation, $85 \%$ rural water supplies and $50-80 \%$ urban water supplies apart from other uses. It is also the only sustainable source of water in drought prone rainfed areas. But, while the utilizable groundwater is $392.70 \mathrm{BCM}$ the stage of extraction is $63.34 \%$, with $22 \%$ of assessment units overexploited or in critical category calling for its scientific management. The following Fig. 1 (a) and (b) present postmonsoon DTW, and Decadal Rise and Fall of water level reflecting stressful groundwater scenario in India (Ground Water Year Book 2020).

In this context Central Ground Water Board (CGWB), the apex organisation and the State Ground Water Departments dealing with groundwater development and management have been carrying out case studies across the country over the last several decades in search of viable solutions of raging or

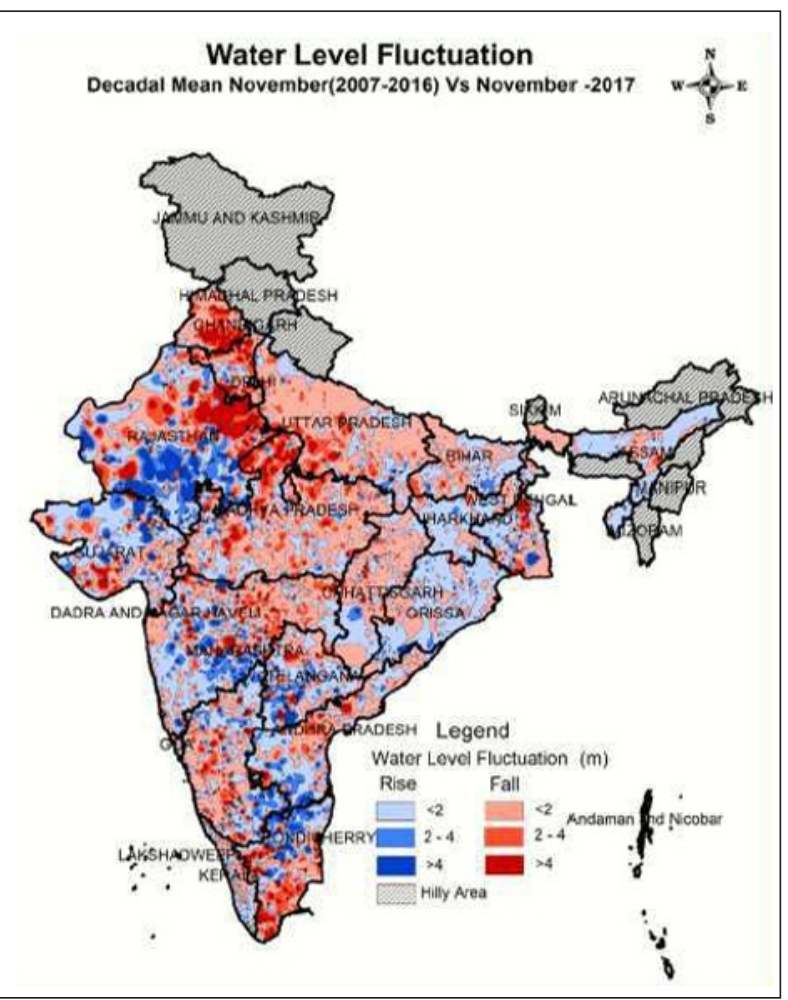

Fig.1. Map of India depicting (a) Post-monsoon depth to water level (DTW) below ground level, and (b) Decadal rise and fall of post-monsoon water level (Source: Ground Water Year Book, CGWB, 2020). 
impending water stress in different parts of the country. The following paras recount in brief the arenas of research and achievements in water management sector in India in the last three decades. The major concern is water sustainability and security through its optimization and augmentation aided by demand and supply management.

1. Optimising all water resources: conjunctive use, economy in water use, regulation of draft and prevention of pollution.

2. Water augmentation: rainwater harvesting, artificial recharge and integrated water management.

\section{WATER CONSERVATION: SCIENCE \& TECHNOLOGY}

In the wake of looming water crisis and rising conflicts of competing water use sectors, while the total rainfall over the country remains the same and hardly $30 \%$ of it is utilizable with conventional technologies, scientists are now striving to improvise augmentation and conservation of water resources without adversely impacting water cycle like optimal use of all water resources, economy and increasing efficiency of water use, and artificial recharge of aquifers.

\section{(A) CONJUNCTIVE USE}

Conjunctive use implies coordinated and harmonious development of surface and ground water. It is the most efficient method of water conservation, which apart from optimal use of water resources, rectifies aberrations in canal irrigation between head reaches and tail ends, ameliorates water logging through vertical drainage, increases irrigation intensity and agricultural production with crop diversification, and maximizes yields per unit volume of water. It calls for assessment of geological and hydrological set-up, periodic availability of water resources commensurate with crop-water requirement vis-a-vis other uses, followed by system analysis, groundwater flow modelling and simulation studies generating alternate scenarios of optimizing the use of water resources. Conjunctive use study in Hirakud command in Odisha was one of the thirteen Pilot Project studies to set models of conjunctive use in similar agroclimatic zones in the country.

\section{Pilot Project Study in Hirakud Command, Odisha (1992- 1996)}

It has a cultural command area of 1,57,018 hectares with irrigation intensity of $170 \%$ and cropping pattern of $98 \%$ paddy in kharif and $68 \%$ in rabi seasons leading to overuse of surface water and excessive recharge to ground water with low crop yield. Water logging prevailed in 7264 square kilometers in post-monsoon season, 1994. The average annual rainfall is $1169 \mathrm{~mm}$. The annual availability of surface water was 1360 MCM and $1494 \mathrm{MCM}$, and utilizable groundwater $508 \mathrm{MCM}$ and $764 \mathrm{MCM}$ in kharif and rabi seasons respectively. To optimize use of water resources and maximise crop production and return from irrigation, and reduction of water logging, several scenarios were generated by system analysis and mathematical modeling cum simulation studies.

Scenario 1: Only canal water with no ground water usage, cropping intensity of $170 \%$. The water balance after predictive simulation shows increase in ground water storage from 169 to $1228 \mathrm{MCM}$ over a period of five years and in evapotranspiration values indicating progressive shallowing of water table.

Scenario 2: For conjunctive use scenario optimization of cropping patten was attempted for maximum use of surface water, the shortage being met from ground water at $200 \%$ cropping intensity with cropping pattern in kharif as paddy $98 \%$ and sugarcane $2 \%$. The cropping intensity in rabi was taken as paddy $38-35 \%$, pulses $36-18 \%$, oilseeds $12-19 \%$, vegetables $10-12 \%$, sugarcane $2 \%$. With canal water use of $70 \%$ and ground water $30 \%$ the post-monsoon water table declined from prevailing $1.2 \mathrm{~m}$ to $1.9 \mathrm{~m}$. This conjunctive use strategy needs construction of additional 17526 energised dug wells.

\section{(B) RAINWATER HARVESTING (RWH) \& ARTIFICIAL RECHARGE (AR)}

In arid and semi-arid India artificial recharge plays a vital role in augmentation and sustainability of water resources and stabilising economy. This is a recent innovation in the management of groundwater reservoirs like enhancing natural recharge rate, replenishing overexploited aquifers, or creating subsurface storage under favourable hydrogeological conditions (CGWB, 1996; Das et al. Nat. Water Conv., NWDA, Bhopal, 1996, \& Sem. Art. Rech., CGWB, N. Delhi, 1998) to be accessed in lean months or at times of need (Fig.2). These may be implemented through soil moisture conservation measures like bench terracing, contour bunding, mulching etc, and also technically simple, cost-effective water harvesting structures like percolation tanks, check dams, johads, gully plugs, injection wells, subsurface dykes etc, for which materials, designs and skill are indigenously available. The feasibility of rainwater harvesting structures in a basin depends on topography, availability of storage space in the moderately porous and permeable formations, aquifer capacity for storage and transmission, source water availability, and lastly response of water table in the neighborhood of proposed groundwater recharge basin.

\section{National Perspective Plan \& Master Plan for Artificial Recharge}

National perspective plan of artificial recharge to

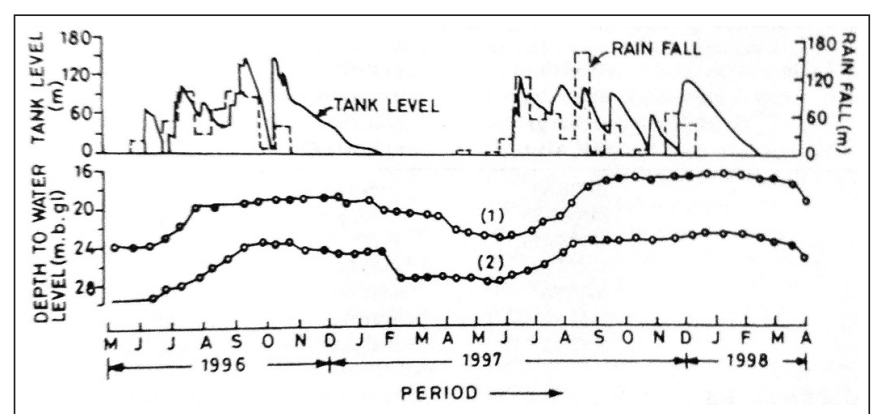

Fig.2. Groundwater level vis-à-vis rainfall and tank level, Ichkheda percolation tank, Watershed TE-17, Jalgaon district, Maharashtra (Jain \& Sharma, Art. Recharge in TE17, CGWB, Tech. Report. CGWB, 1999). 
groundwater utilizing surplus monsoon runoff (CGWB, 1996) is the product of studies by CGWB (1993-1996) laying down the methodology of planning artificial recharge in India. The Plan gave a policy frame of artificial recharge schemes in the country. The studies further showed feasibility of salvaging 21 MhaM of noncommitted monsoon runoff, out of which 16.05 MhaM may be utilized in areas where water table is naturally deep or depleted due to overexploitation and where geohydrological conditions permit, to augment groundwater resources creating subsurface storage. Subsurface geological formations may be treated as 'ware houses' to store the recharge water. The infiltration rates of recharge water under prevailing soil conditions in India vary from 5 to $25 \mathrm{~mm} /$ hour enabling 1.2-6 m column of water to percolate in 100 days. The idea is to saturate unsaturated vadose zone up to 3-5 m below ground level by small cost-effective artificial recharge structures or groundwater conservation measures. The subsurface reservoirs will be free from evaporation losses, effect raising of water table reducing cost of water lifting, ensure sustainability of existing groundwater abstraction system for additional 3-4 months (Fig.2), increase non monsoon river flows among other benefits. This plan formed the bedrock of CGWB's Master Plan for Artificial Recharge (2002) revised in 2013 and 2020 which identified a total area of 11.23 lakh sq. $\mathrm{km}$ in the country with deep water level and declining water level trend, and available subsurface storage space of 537.349 BCM for the purpose subject to favorable hydrological and geohydrological conditions.

\section{INTEGRATED WATER MANAGEMENT: WATERSHED DEVELOPMENT}

A watershed is an ecosystem encompassing all its elements like environment, physiography, pedology, geology, hydrology, agroforestry, biodiversity, and the services they provide in their entirety. Hence any development plan should integrate all these components for an inclusive growth. The aims of the watershed development are conserving every drop of rainwater, controlling soil erosion, increasing soil moisture and recharge, maximizing productivity per unit area and per unit water despite weather adversities; and thus ensuring sustainability of the ecosystem in the watershed. This model has set the trend for all round growth in drought affected rainfed areas in the country through revival of traditional knowledge and practices like construction of johads, check dams, tanks and slew of time-tested water conservation measures. Das (JGSI, March 2015) quoted number of cases starting with Arwari watershed in Rajasthan which was the first successful case of community driven watershed management. The following is a Demonstrative Artificial Recharge Project study in brief.

\section{Honnarghata Sub-watershed (2010-2013)}

Prior to implementation of the project the stage of ground water development was $173 \%$ in Honnaghatta sub-watershed, in Doddaballapura taluk, Bangale Rural district, Karnataka (Farooqi et al. IGWC-2017).). The area experiences dry climate with temperature varying from $16^{\circ}$ to $35^{\circ} \mathrm{C}$. The average

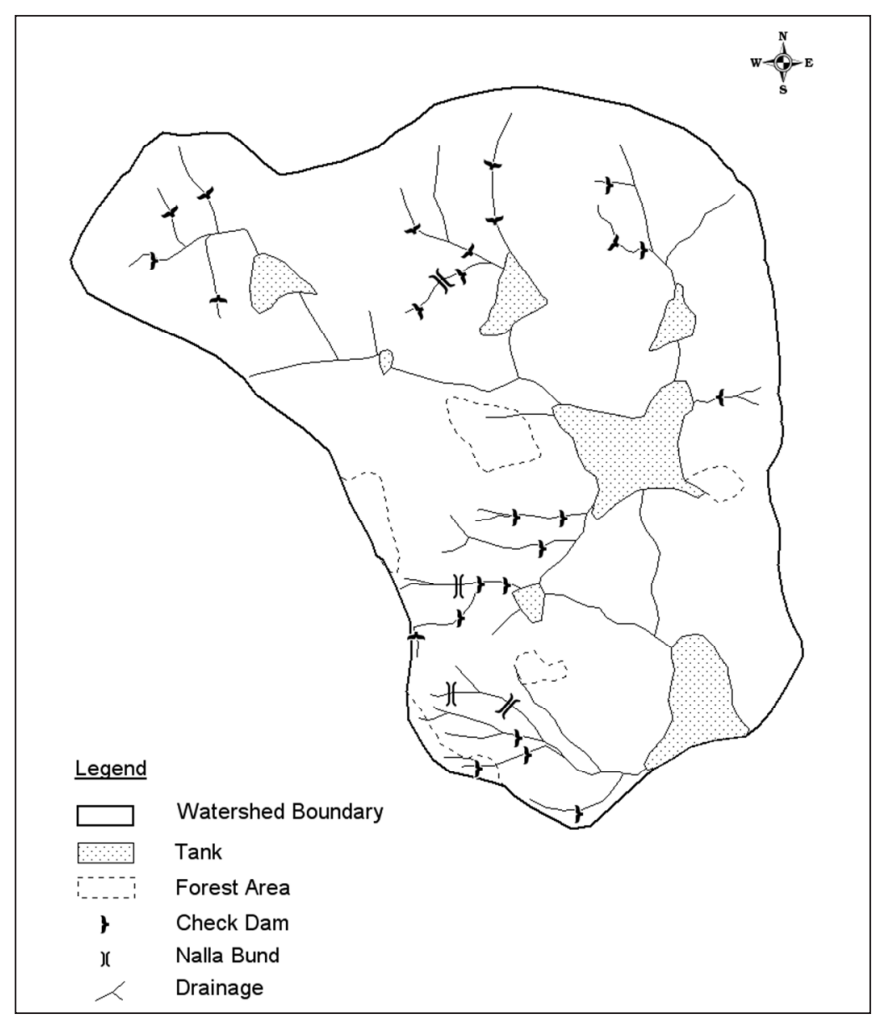

Fig.3. Location of Artificial Recharge structures in Honnarghata sub-watershed (Farooqi et al. IGWC-2017).

monsoon rainfall is $662 \mathrm{~mm}$. The general topography of the area is undulating, full of ravines and gullies and covered by cultivable land of low productivity due to severe soil erosion. Geologically, the dominant formations are Precambrian crystallines. The weathered zone ranges from 14 to $18 \mathrm{~m}$. Agriculture is the main stay of the people in the area. Out of the estimated 8.53 MCM of runoff the non-committed surplus monsoon runoff is $6.56 \mathrm{MCM}$, which goes waste. Ground water is the principal source catering to water requirements which results in its overexploitation and drying up of the phreatic aquifer. In the pre-project period (2009), annual recharge in the watershed was only 1.017 MCM against total draft of 1.759 MCM. Hence it was planned to harness a part of the noncommitted surplus runoff to augment the aquifer recharge through suitable artificial recharge structures. Thus, under the integrated water management plan 25 check dams, 27 rubble checks and 4 nallah bunds were constructed during 2010-13 (Fig.3) in addition to roof top rainwater harvesting and desilting/ renovation of existing surface water bodies. Implementation of the Action Plan may effect saving 0.7947 MCM of groundwater.

Impact assessment revealed rise in bore well water levels in the range of 0.89-2.47 m, increase in well yields 0.25-2.0 lps, pumping duration 15-35 minutes, and command area of the bore wells $0.5-1.5$ acres. The rubble checks helped in retention of moisture in the soil.

\section{URBAN WATER SUPPLIES (2009-11)}

A case study conducted in the fast growing metropolis of Bengaluru dwelt on the vital questions of water sustainability, equity and governance in the sprawling urban centers of the country (Mem. no.79, Geol. Soc. India, 2011). 
With projected population of 125 lakhs by 2036 the water demand in Bengaluru by various estimates, may soar to 25503000 MLD. The primary source of water supply of the city was Cauvery river and its tributary Arkavathy, in addition to innumerable lakes dotting the city and around. At present the Cauvery water supplies from various reservoirs are around 1500 MLD. But transmission losses or physical losses (UFW) substantially reduce the actual utilization to around 900 MLD against a demand of more than 1800 MLD in the city. Illegal encroachment, sand mining, garbage dumping and discharge of untreated sewage have destroyed most of the water bodies denting freshwater supplies to the city and the scope of groundwater recharge. Thus, bore wells have emerged as an important supplementary source of water for the city but in the process overexploiting groundwater and drying up aquifers down to 240 meters with deepening of water levels.

The four major components of urban water cycle are river water, lake water, groundwater and recycled grey water. Integrated management of all these components of the water cycle is the foundation of a smart city. Conservation, optimal use and augmentation should be the cornerstone of water management in Bengaluru. The lakes and water bodies need to be revived through desilting, and prohibiting discharge of untreated waste waters/sewage, or dumping of garbage. Studies indicated that a total of 10,557 artificial recharge structures (percolation tanks, point recharge structures, checkdams, dry wells and tiny water bodies or tanks) are feasible in the Arkavathy basin in addition to roof top rainwater harvesting, which will effect a total artificial recharge to groundwater to the tune of 328.2 MCM (Renuka Prasad, GSI Mem79, 2011). Further, recycling of treated sewage water of nearly 800-1000 MLD (i.e., $80 \%$ of water used) combined with plugging of transmission losses of Cauvery water (up to even 40-53\%) may sufficiently augment the utilizable water supply for the city. The capacity of sewage water treatment plants (STPs) needs to be substantially enhanced with dual water supply system. Lastly all water-related agencies in the metropolitan city should be brought under a single umbrella organization for better coordination, and achievement of the goals (Ravishankar: Spl. Publ. no.5, Geol. Soc. India, 2016, p.47).

This is now a model of water management for all urban centers.

\section{RIVER REJUVENATION (2013-2014)}

Surface water and groundwater are integral parts of the water cycle. River recharges groundwater in monsoon and vice versa in non-monsoon months. The rivers in India are in distress with flows depleted and polluted due to construction of dams and canals obstructing and diverting flows; overexploitation of ground water; discharge of sewage and wastewater without treatment, degradation of catchment as also siltation in river channel. Generation of flows is an interactive product of the elements of environment, and ecosystem of the watershed, namely rainfall, landform, forest, soil, vegetation, geology, and subsurface water. Hence the river rejuvenation is interlinked with integrated watershed development (Spl. Publ. no.7, Geol. Soc. India, 2020)
Kumudvathy, a tributary of the Arkavathy, and the lifeline of millions is in decadence with degraded catchment and severely diminished flows. The Art of Living team in Bengaluru launched its rejuvenation program which included erosion control through boulder checks, groundwater augmentation through well recharge and rejuvenation of water bodies like 'kalyanis' (step wells) and tree planting. The infiltrating water recharges shallow aquifers and in turn deeper aquifers. A total of 223 tanks have been desilted and three lakh trees have been planted along the stream network. This has helped in arresting soil erosion, flash floods and in infiltration to increase soil moisture and groundwater recharge. As a result, the streams down the line at lower altitudes become effluent (Spl. Pub. No. 7, 2020).

Impact assessment in the Project shows restoration of depleted groundwater and streamflows, increase in natural vegetation, changing of cropping pattern from single to multi crop, eco-restoration by environmental development leading to ecohydrological conservation. Community participation as also linkage with technical/financial institutions are vital.

\section{WAY FORWARD}

Various agencies including Central Ground Water Board have embarked on Special Project Studies which revealed few fundamental solutions to the impending water crisis.

1. Conjunctive use should be the foundation of water supply planning, especially in canal commands to redress water shortage, rectify water logging, and increase its productivity.

2. Integrated watershed treatment including rainwater harvesting and artificial recharge in drought prone and rainfed areas will ensure food and drinking water security, economic prosperity, perennial flows in rivers, leaving ecological and environmental balance undisturbed.

3. In urban areas integrated use of all components of water cycle will address water shortage and ensure its sustainability and equity.

4. Linkage with technical and financial institutions and community participation are integral parts of implementation of the watershed development program.

5. Scientific and technological innovations will boost knowledge in water management and reinforce traditional practices.

(i) Detailed studies of geomorphology, surface hydrology, subsurface ground water regime aided by remote sensing and geophysics for village level water resource planning.

(ii) Modeling of groundwater flow system to understand the system which will help in water resource planning process

(iii) Monitoring groundwater level and quality for impact assessment of development.

(iv) Protection of resource from overexploitation and pollution.

(v) Adoption of rainfed agriculture, drip irrigation, and water economy in all uses to conserve water.

(vi) Development of models of water management in different agroclimatic and hydrogeological zones.

6. Framing Groundwater Policy specific to drought prone rainfed areas. 